\title{
STUDI KASUS MINAT MEMBACA BUKU PADA MAHASISWA PGSD UWGM SAMARINDA
}

\author{
Siska Oktaviani, Nurul Hikmah \\ Surel: Siskaavianii@gmail.com
}

\begin{abstract}
This study aims to determine the condition of interest in reading books in PGSD UWGM final semester students who are in the process of writing a thesis. This type of research is a qualitative study using a case study approach. The research site is in UWGM Samarinda Campus located at KH. Wahid Hasyim No. 28, Samarinda Utara District,Kaltim Province. Data sources were obtained from students and data from the library and UWGM environment. Data collection techniques consist of interviews, observation and documentation. Data analysis techniques are done through data reduction, data display and conclusion drawing/verification. Data validity was also tested using triangulation techniques, namely triangulation techniques. From the results of interviews, observations and documentation obtained a description that by writing a thesis can generate interest in reading students because by reading, students can obtain references and information needed in writing a thesis.
\end{abstract}

Keywords : Interest; Reading; Books; Students

\begin{abstract}
ABSTRAK
Penelitian ini bertujuan untuk mengetahui kondisi minat membaca buku pada mahasiswa/i prodi PGSD UWGM semester akhir yang sedang dalam proses penulisan skripsi. Jenis penelitian ini yaitu kualitatif yang menerapkan pendekatan studi kasus. Tempat penelitian di UWGM Samarinda yang lokasinya di Jalan KH.Wahid Hasyim No.28 Kecamatan Samarinda Utara, Kota Samarinda, Provinsi Kaltim. Sumber data didapat dari mahasiswa dan data-data dari perpustakaan serta lingkungan UWGM. Teknik pengumpulan data yaitu wawancara, observasi dan dokumentasi. Teknik analisis data dilakukan melalui mengumpulkan data, menyajikan data dan menyimpulkan. Dilakukan pula uji keabsahan data dengan menerapkan teknik triangulasi, yaitu triangulasi teknik. Dari hasil wawancara, observasi dan dokumentasi dapat dideskripsikan dengan penulisan skripsi dapat memunculkan minat membaca mahasiswa, dikarenakan dengan membaca, mahasiswa bisa memperoleh referensi dan informasi yang diperlukan dalam penulisan skripsi.
\end{abstract}

Kata Kunci : Minat; Membaca; Buku; Mahasiswa

\section{PENDAHULUAN}

Kampus sebagai institusi akademik adalah tempat civitas akademika seperti rektor, dosen, mahasiswa dan pegawai universitas. Bagi mahasiswa, kampus adalah tempat untuk mereka menggali dan mengasah ilmu pengetahuan agar dapat mengetahui, mengerti dan memahami sesuatu sesuai dengan bidang ilmu mereka.

Tak salah, jika mahasiswa/idapat menggantungkan impian, cita-cita dan masa depan di kampus karena 
menganggap kampus sebagai tempat belajar.

Untuk memperoleh ilmu dan pengetahuan dengan mudah dan cepat, salah satu kegiatan belajar yang cukup efektif adalah membaca buku, karena baik dosen maupun mahasiswa cukup hanya dengan memilih buku bacaan, mulai membaca kata demi kata dan memahami isinya. Oleh sebab itu, membaca buku sebaiknya menjadi kegiatan utama yang dilaksanakan oleh citivitas akademika terutama mahasiswa, karena dengan membaca buku dapat menambah pengetahuan, menjadi sumber inspirasi dan mengasah kemampuan berpikir kritis.

Tetapi faktanya, masalah yang sampai sekarang ini banyak ditemukan yaitu rendahnya minat membaca pada masyarakat di Indonesia termasuk mahasiswa. Hal tersebut terbukti pada tahun 2012, Badan Pusat Statistik (BPS) membuat kita menghela nafas panjang. Karena minat membaca masyarakat di Indonesia ada penurunan setiap tahunnya. Kemudian tahun 2003 sebesar $23,70 \%$ masyarakat Indonesia menghabiskan waktu dengan membaca. Persentase tersebut menurun pada tahun 2006 menjadi $23,46 \%$ dan terus mengalami penurunan pada tahun 2012 menjadi $17,66 \%$ yang gemar membaca. Survei yang sama juga membuktika bahwa masyarakat Indonesia lebih memilih kegiatan lain ketimbang membaca seperti dengan menonton televisi $(91,68 \%)$, olahraga $(24,57 \%)$ dan mendengarkan radio $(18,57 \%)$.

Najwa Shihab selaku Duta Baca Perpustakaan Nasional Republik Indonesia menyatakan bahwa Indonesia ada pada posisi urutan ke 60 dari 61 negara yang berkaitan dengan minat baca, hal ini secara tidak langsung membuktikan bahwa minat baca warga Indonesia sangat kurang dibandingkan negara-negara lainnya.

Menurut Harian Kompas, terbitan 12 Juni 2009 menyebutkan mahasiswa/i sebelum dan sesudah era modern memiliki minat baca yang berbeda, hal ini terlihat dari mahasiswa sebelum era modern memiliki semangat dan motivasi tinggi untuk membaca buku walaupun fasilitas masih terbatas, sedangkan mahasiswa era modern kurang minat untuk membaca walaupun sekarang perpustakaan dan pembelian referensi mudah ditemui. Minat baca yang menurun ini, kemungkinan dipengaruhi oleh majunya teknologi informasi. Dimana terdapat beragam hiburan yang menarik namun tidak mengikutsertakan media buku.

Kemudian hasil studi penelitian relevan, contohnya Studi Tentang Minat Baca Mahasiswa FKIP UNY, oleh Deni Hardianto. Dapat disimpulkan bahwa bahwa minat baca mahasiswa FIP UNY dalam kategori rendah, hal itu bisa dilihat dari hasil survei yang menyatakan presentase sebesar 79,20 persen mahasiswa kadang-kadang mempunyai keinginan membaca.

Kurangnya minat membaca buku nampaknya juga terjadi pada 
mahasiswa di PGSD UWGM Samarinda hal tersebut bisa dilihat dari partisipasi mahasiswa saat mengikuti perkuliahan. Peneliti banyak menemui, mahasiswa cenderung diam, mendengarkan dan menerima saja materi yang disampaikan dosen, mahasiswa malu dan enggan untuk bertanya. Ketika dosen bertanya tentang alasan mahasiswa/i tidak ingin bertanya, mahasiswa/i banyak memiliki rasa kebingungan dan takut jika pertanyaan yang mereka ajukan tidak bermutu. Mutu pertanyaan sebetulnya bisa ditelusuri dari hasil bacaan mereka. Mahasiswa yang tidak dapat melontarkan pertanyaan bermutu, disebabkan mahasiswa/i tidak membaca terlebih dahulu terkait materi yang disampaikan dosen.

Mahasiswa/i yang menuntut ilmu di universitas/kampus tidak akan pernah terpisah dari kegiatan belajar dan menyelesaikan kewajiban akademiknya. Bagi mahasiswa semester akhir, kewajiban akademik mereka adalah penyusunan skripsi. Mahasiswa/i diwajibkan mengambil mata kuliah skripsi, karena skripsi digunakan sebagai persyaratan untuk mendapatkan gelar akademis sebagai sarjana. Namun, peneliti menemukan skripsi yang mahasiswa/i kerjakan masih minim referensi.

Menurut Huda (2011) skripsi merupakan karya ilmiah hasil penelitian yang ditulis oleh mahasiswa/i program sarjana yang menjelaskan tentang topik atau bidang tertentu berdasarkan hasil kajian teori para ahli. Proses belajar dalam skripsi berlangsung secara per orang, berbeda dengan mata kuliah lain yang umumnya dilaksanakan secara berkelompok. Menulis skripsi dapat memiliki pengalaman belajar kepada mahasiswa/i dalam menyelesaikan masalah secara ilmiah, dengan cara mengerjakan penelitian sendiri, menganalisis, membuat kesimpulan dan menyusunnya sampai terbentuknya karya tulis ilmiah.

Dalam proses penulisan skripsi, tidak terlepas dari masalah yang biasanya dihadapi mahasiswa diantaranya mahasiswa yang sedang menulis ternyata masih banyak yang kurang memahami apa yang ditulisnya, sulitnya menentukan permasalahan serta penentuan judul skripsi, sulitnya konsultasi dengan dosen pembimbing dan kurangnya literatur penunjang dalam penulisan skripsi.

Ada faktor-faktor yang mempengaruhi dalam penyelesaian skripsi. Menurut Siang (2009) menyatakan bahwa ada dua faktor hambatan dalam penyelesaian skripsi yaitu faktor dari dalam diri dan faktor dari luar diri. Faktor dalam diri contohnya kurangnya semangat, minat atau motivasi yang ada dalam diri mahasiswa untuk menyelesaikan skripsi dan rendahnya kemampuan akademik yang menghambat munculnya ide, sedangkan faktor dari luar diri mahasiswa contohnya sulitnya menemukan permasalahan sehingga terbentuknya judul, sulitnya 
mencari literatur atau permasalahan lain seperti dosen pembimbing yang sulit ditemui.

Dari pendapat di atas yang merupakan salah satu faktor yang mempengaruhi seseorang dalam penulisan dan penyelesaian skripsi adalah minat. Menurut KBBI (2011) minat yaitu ketertarikan hati yang besar terhadap sesuatu, penuh kemauan untuk melakukan sesuatu. Salah satu minat yang harus ada dalam diri mahasiswa dalam penulisan skripsi adalah minat membaca.

Susanto

menjelaskan yang dikatakan minat adalah ketertarikan jiwa yang dimiliki manusia terhadap suatu objek, yang diikuti oleh perasaan bahagia, karena memiliki ada rasa kepentingan dengan objek tersebut.Menurut Ratnasari (2011) minat membaca adalah kemauan yang besar dilakukan dengan rasa senang untuk melakukan kegiatan membaca sehingga membuat seseorang dengan keinginan sendiri untuk membaca karena kesadaran bahwa dengan membaca dapat memperoleh manfaat bagi diri sendiri. Hal itu yang menjadi landasan bahwa dengan adanya minat membaca dapat membantu mahasiswa dalam penulisan dan penyelesaian skripsi karena dengan adanya minat tersebut mahasiswa dapat dengan mudah mencari informasi dari literatur yang dibutuhkan.

Kemudian Sadirman (2010:73) minat seorang anak banyak disebabkan oleh faktor internal, contoh memfokuskan perhatian, kemauan, motivasi, dan kebutuhan. Sampai sekarang ini dalam proses belajar mengajar, minat bisa mempengaruhi kualitas dalam mencapai hasil belajar anak dalam bidang studi tertentu.

Menurut Kamus Besar Bahasa Indonesia (2011) membaca yaitu melihat dan memahami isi dari apa yang ditulis (dengan bersuara atau di dalam hati) selain itu membaca juga bisa diartikan sebagai mengeja atau melafalkan tulisan. Sedangkan menurut Fanany (2012) mengemukakan bahwa membaca yaitu proses untuk mengenal kata dan memadukan arti kata dalam kalimat dan struktur bacaan, sehinggal hasil akhir dari proses membaca yaitu seseorang dapat menyimpulkan intisari bacaan.

Menurut Ahmad (2010) menjelaskan bahwa membaca adalah proses yang dilaksanakan dan difungsikan oleh pembaca untuk memperoleh pesan yang ingin disampaikan oleh penulis dengan perantara media bahasa tulisan atau kata-kata. Alfrido (2013) mengemukakan bahwa membaca merupakan proses untuk mengasah dan meningkatkan intelektualitas seseorang Selanjutnya menurut Dalman (2014:141) minat baca adalah rasa termotivasi ingin memahami kata, kalimat dan isi yang termuat dalam isi tulisan bacaan atau buku tersebut, sehingga yang membaca dapat paham hal-hal yang termuat pada bacaan itu. Menurut Simanjuntak (2011) minat baca akan menjadi kebiasaan membaca 
apabila tersedia bahan bacaan yang sesuai untuk dibaca dan ada cukup waktu untuk membaca.

Dalman juga menjelaskan bahwa tujuan membaca dapat membangkitkan rasa paham seseorang dalam memahami suatu bacaan. Ada macam-macam variasi tujuan membaca, yaitu membaca untuk tujuan telaah ilmiah; untuk tujuan mengambil garis besar atau point penting pada bacaan; untuk menikmati karya sendiri dan karya orang lain; dan untuk memanfaatkan waktu yang luang; untuk mencari keterangan tentang istilah.

Dari berbagai pendapat di atas maka peneliti bisa simpulkan bahwa minat adalah suatu rasa yang lebih disenangi atau rasa ketertarikan pada suatu aktivitas yang dilakukan dengan adanya kemauan, kecenderungan untuk memperhatikan aktivitas tersebut tanpa ada seorang pun yang menyuruh, dilaksanakan dengan kesadaran diri sendiri dan perasaan yang mengikuti rasa senang.

Tujuan penelitian ini adalah untuk mengetahui minat membaca buku pada mahasiswa semester VIII PGSD UWGM Samarinda yang sedang dalam proses penulisan skripsi atau tugas akhir.

\section{METODE PENELITIAN}

Dalam penelitian ini, peneliti menggunakan penelitian kualitatif (qualitative research). Sugiyono (2014) menjelaskan bahwa metode penelitian kualitatif merupakan metode penelitian yang fungsinya untuk meneliti pada kondisi objek yang alamiah (sebagai lawannya adalah eksperimen) dimana posisi peneliti sebagai instrumen kunci, teknik pengumpulan data dilakukan secara triangulasi (gabungan), analisis data yang sifatnya induktif dan hasil penelitian lebih mengutamakan makna daripada generalisasi.

Secara khusus, dalam penelitian ini peneliti menerapkan pendekatan studi kasus, dimana ini sebagai inkuiri empiris yang menyelidiki fenomena dan konteks tidak terlihat dengan tegas dan dimana multi sumber bukti digunakan. Creswell (2010) menyatakan bahwa studi kasus adalah strategi penelitian dimana di dalamnya peneliti menyelidiki secara cermat suatu program, peristiwa, aktivitas, proses atau sekelompok individu.

Tempat yang digunakan sebagai penelitian adalah Universitas Widya Gama Mahakam Samarinda yang lokasinya di jalan KH. Wahid Hasyim No. 28 RT.007 Kelurahan Sempaja Selatan, Kecamatan Samarinda Utara, Kota Samarinda, Provinsi Kalimantan Timur. Sampel dalam penelitian yaitu bagian kecil dari anggota populasi yang diambil menurut prosedur tertentu sehingga bisa mewakili populasinya. Sugiyono (2014). Dalam penelitian ini, teknik sampling yang diterapkan yaitu purposive sampling. Menurut Sugiyono (2016) purposive sampling yaitu teknik pengambilan berdassarkan pertimbangan tertentu. Dalam penelitian ini yang menjadi sampel adalah mahasiswa PGSD semester akhir yang sedang dalam tahap penulisan skripsi. Adapun 
kriteria yang dijadikan sampel adalah mahasiswa dengan IPK tertinggi dan terendah dari masingmasing kelas.

Untuk memperoleh data yang akan dibutuhkan teknik pengumpulan data dalam penelitian ini adalah observasi, wawancara dan dokumentasi. Analisis data yang diterapkan dalam penelitian ini yaitu non statistik yang menerapkan analisis data deskriptif kualitatif yaitu analisis data bukan dalam bentuk angka melainkan dalam bentuk laporan dan uraian deskriptif.

Agar data yang didapatkan nantinya sesuai dengan kerangka kerja, maka ditempuh tiga tahap utama dalam penelitian ini. Miles dan Huberman (Sugiyono, 2014) menjelaskan bahwa kegiatan dalam analisis data kualitatif dilaksanakan secara interaktif dan berlangsung terus menerus sampai tuntas, sehingga datanya jenuh. Kegiatan dalam menganalisis yaitu mengumpulkan data, menyajikan data dan menarik kesimpulan.

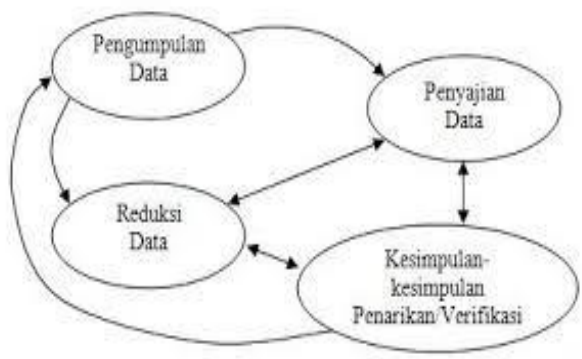

\section{Gambar 1. Analisis data kualitatif menurut Miles dan Huberman}

- Data Reduction (Reduksi Data)

Mereduksi data berarti memilih hal-hal yang pokok, memfokuskan pada hal-hal yang penting, kemudian dicari tema dan polanya dan membuang yang tidak perlu. Reduksi data bertujuan untuk mempermudah pemahaman peneliti terhadap data yang telah terkumpul dari hasil penelitian. Dalam hal ini peneliti akan mengumpulkan informasi dan data dari narasumber dan informasi lain untuk dapat mengkaji lebih detail. Di sini peneliti mengumpulkan data dan informasi mengenai minat membaca buku pada mahasiswa PGSD UWGM yang diperoleh dan terkumpul dari hasil wawancara, observasi dan dokumentasi.

- Data Display (Penyajian Data)

Setelah data direduksi, maka langkah selanjutnya adalah menyajikan data. Data hasil reduksi ditampilkan ke dalam bentuk yang mudah dipahami. Dalam penelitian kualitatif penyajian data bisa dilakukan dalam bentuk uraian singkat, bagan hubungan antar kategori, flowchart dan lain-lain.

- Conclusion Drawing/Verification (Penarikan

Kesimpulan/Verifikasi)

Langkah selanjutnya dalam analisis data kualitatif adalah penarikan kesimpulan dan verifikasi. Sugiyono (2012) menyatakan bahwa metode ini bertujuan untuk menyajika deskripsi secara sistematis, faktual dan akurat mengenai fakta-fakta, sifat serta hubungan fenomena yang diselidiki.

Kesimpulan ini akan diikuti dengan bukti-bukti yang diperoleh ketika peneliti di lapangan. Sedangkan verifikasi dimaksudkan untuk penentuan data akhir dan keseluruhan 
proses tahapan analisis, sehingga keseluruhan permasalahan mengenai minat membaca buku pada mahasiswa PGSD UWGM dapat terjawab sesuai dengan kategori data.

Dalam menguji keabsahan data, peneliti menerapkan teknik triangulasi adalah pemeriksaan keabsahan data yang memanfaatkan sesuatu yang lain diluar data untuk keperluan pengecekan atau sebagai pembanding terhadap data tersebut, agar data yang didapatkan akan lebih konsisten sehingga menjadi suatu data yang valid dan dapat dipertanggung jawabkan.

Kemudian menguji keabsahan data yang berkaitan dengan masalah yang diteliti maka peneliti menggunakan triangulasi teknik. Menurut Sugiyono (2014) triangulasi teknik menguji data yang dilaksanakan dengan cara mengecek data kepada sumber yang sama dengan teknik yang berbeda.

\section{HASIL PENELITIAN DAN PEMBAHASAN}

Untuk mengetahui hasil penelitian yang berkaitan dengan minat membaca buku pada mahasiswa semester VIII PGSD UWGM Samarinda yang sedang dalam proses penulisan skripsi atau tugas akhir, peneliti menggunakan penelitian kualitatif dimana peneliti harus memaparkan, menggambarkan dan menjelaskan data yang telah didapatkan dari hasil observasi, dokumentasi dan wawancara bersama narasumber.
Wawancara dilaksanakan dengan teknik purposive sampling terhadap 8 orang narasumber dengan menggunakan inisial, yaitu BW, MJ, WR, EL, GP, NV, AF dan SI. Data yang belum lengkap dari hasil wawancara, dilengkapi dengan data hasil observasi langsung secara partisipatif yang dilaksanakan lagi lebih lanjut sampai tuntas dan data jenuh. Untuk memperdalam data hasil wawancara dan observasi, maka peneliti menelusuri dokumen yang ada.

Untuk memperkuat data hasil wawancara dan observasi, maka dilakukan penelusuran terhadap dokumen yang ada.

- Kesukaan mahasiswa dalam membaca

Dari hasil wawancara terdapat 3 mahasiswa yang minat dalam membaca dan 5 mahasiswa tidak minat dalam membaca. Dan dapat peneliti simpulkan bahwa minat membaca mahasiswa PGSD UWGM masih tergolong rendah.

- Jenis buku yang dibaca

Dari pemaparan disimpulkan bahwa mahasiswa lebih suka membaca cerita fiksi ketimbang buku-buku umum perkuliahan, dan jika pun mahasiswa membaca karena ada tugas perkuliahan.

- Tahap penulisan skripsi

Dari hasil wawancara terdapat 5 mahasiswa telah sampai pada tahap seminar proposal dan melanjutkan ke tahap selanjutnya yaitu penelitian dan penulisan hasil penelitian untuk menyelesaikan skripsi 
mereka sebelum maju pendadaran, sedangkan dari 3 mahasiswa masih ada proses penyelesaian proposal dan belum sampai pada tahap seminar proposal.

Hal tersebut sesuai dengan hasil observasi yang peneliti lakukan karena peneliti juga sebagai dosen pembimbing salah satu narasumber.

- Kendala dalam penulisan skripsi

Dari hasil wawancara terdapat 5 mahasiswa telah sampai pada tahap seminar proposal dan melanjutkan ke tahap selanjutnya yaitu penelitian dan penulisan hasil penelitian untuk menyelesaikan skripsi mereka sebelum maju pendadaran, sedangkan dari 3 mahasiswa masih ada proses penyelesaian proposal dan belum sampai pada tahap seminar proposal.

Hal tersebut sesuai dengan hasil observasi yang peneliti lakukan karena peneliti juga sebagai dosen pembimbing salah satu narasumber.

- Referensi yang digunakan dalam penulisan skripsi

Dari pemaparan hasil wawancara kita ketahui bahwa narasumber menggunakan buku, artikel dan skripsi untuk dijadikan bahan referensi skripsi.

- Jumlah referensi yang digunakan dalam penulisan skripsi
Dari pemaparan hasil wawancara kita ketahui bahwa jumlah referensi yang narasumber gunakan dalam penulisan skripsi beragam dan lebih banyak menggunakan buku.

- Sumber referensi yang digunakan dalam penulisan skripsi

Dari pemaparan hasil wawancara kita ketahui bahwa sumber referensi yang narasumber gunakan dalam penulisan skripsi didapat karena narasumber beli sendiri dan pinjam di perpustakaan, baik itu perpustakaan daerah, kota dan Unmul. Dan untuk perpustakaan UWGM, narasumber lebih dominan membaca dan meminjam skripsi. Dikarenakan kurangnya referensi buku untuk mahasiswa PGSD.

- Minat membaca karena penulisan skripsi

Dari pemaparan hasil wawancara yang dilakukan dengan narasumber di atas diketahui bahwa dengan penulisan skripsi memunculkan minat membaca karena dengan membaca dapat membantu mahasiswa dalam penulisan dan penyelesaian skripsi.

\section{Pembahasan}

Dari hasil wawancara yang didapat ketertarikan mahasiswa dengan membaca masih rendah. Mahasiswa hanya membaca jika mendapat tugas perkuliahan yang mengharuskan mereka mencari referensi dan membacanya. 
Ketertarikan mahasiswa membaca lebih pada buku-buku fiksi ketimbang buku-buku perkuliahan. Dalam kegiatan perkuliahan seharihari, mahasiswa juga jarang berkunjung ke perpustakaan. Mahasiswa berkunjung ke perpustakaan jika ada tugas yang diberikan dosen.

Untuk mahasiswa semester akhir yang sedang dalam tahap penyusunan dan penulisan skripsi ini kegiatan membaca menjadi kegiatan pokok. Dari hasil wawancara dan observasi diketahui bahwa mahasiswa semester akhir lebih sering ke perpustakaan untuk mencari referensi. Referensi yang mereka cari di perpustakaan berupa buku dan skripsi terdahulu. Mereka juga menggunakan artikel sebagai referensi yang mereka bisa dapatkan di internet. Mahasiswa juga ada yang membeli buku untuk referensi karena buku yang mereka butuhkan tidak ada di perpustakaan.

Selain perpustakaan UWGM yang mahasiswa kunjungi, mereka juga mengunjungi perpustakaan di luar kampus seperti perpustakaan UNMUL, perpustakaan daerah dan perpustakaan kota. Alasan mereka mencari referensi di luar perpustakaan kampus karena minimnya referensi contohnya buku yang tersedia di perpustakaan universitas.

Dari hasil wawancara, observasi dan dokumentasi diperoleh gambaran bahwa ketertarikan mahasiswa PGSD UWGM dengan kegiatan membaca masih rendah. Kegiatan membaca tidak menjadi rutinitas penting, mahasiswa hanya melakukan kegiatan membaca saat menyelesaikan tugas perkuliahan. Namun dengan penulisan skripsi dapat memunculkan minat membaca mahasiswa karena dengan membaca, mahasiswa/i dapat memperoleh referensi dan informasi yang diperlukan dalam penulisan skripsi, searah dengan penjelasan Rahim (2008) yang menyatakan bahwa minat baca yaitu rasa ingin seseorang untuk membaca yang disertai dengan usaha untuk melakukannya.

Walaupun secara langsung mahasiswa tidak menyukai membaca, tetapi dikarenakan penulisan skripsi, mereka berusahan untuk menemukan referensi yang mereka cari, mulai membaca dan memahaminya. Referensi yang susah mahasiswa dapatkan mempengaruhi penyelesaian penulisan skripsi. Karena mahasiswa harus mencari referensi yang sesuai dengan judul skripsi. Sehingga membutuhkan waktu dalam mencari referensi yang dibutuhkan.

Referensi yang mahasiswa gunakan dalam penulisan skripsi berupa buku dan skripsi yang mahasiswa dapatkan dengan membeli dan meminjamnya di perpustakaan. Kemudian mahasiswa juga mendapat referensi dari artikel yang mereka dapatkan melalui internet.

\section{SIMPULAN}

Berdasarkan hasil penelitian yang didapat dari hasil wawancara, observasi dan dokumentasi dengan 
delapan narasumber yang bisa disimpulkan bahwa penulisan dan penyelesaian skripsi memunculkan minat membaca buku pada mahasiswa. Karena dengan membaca buku mahasiswa dapat memperoleh informasi untuk dapat menyelesaikan skripsi. Hendaknya dosen meningkatkan minat baca mahasiswa dengan menginformasikan bahan bacaan yang menarik mahasiswa agar mau membaca, mencari bahan bacaan yang sesuai dengan topik yang akan dijelaskan di kelas dan memberikan tugas yang mengharuskan mahasiswa untuk membaca.

\section{DAFTAR RUJUKAN}

Ahmad, Listiyanto. 2010. Speed Reading: Teknik dan Metode Membaca Cepat. Yogyakarta: A Plus Books

Alfrido, 2013. Menghadirkan Home Library dalam Hunian. Yogyakarta: Laksana.

Alwi, Hasan. 2011. Kamus Besar Bahasa Indonesia. Jakarta: Gramedia Pustaka Utama.

Creswell, J.W. 2010. Research Design: Pendekatan Kualitatif, Kuantitatif, dan Mixed. Yogjakarta: PT Pustaka Pelajar.

Dalman. 2014. Keterampilan Membaca. Jakarta: Rajawali Pers.

Fanany, El. 2012. Teknik Membaca Cepat Trik Efektif. Yogyakarta: Araska.
Herdianto, Deni. 2011. Studi Tentang Minat Baca Mahasiswa Fakultas Ilmu Pendidikan UNY. Majalah Ilmiah Pembelajaran. 7(1): 108-121.

Rahim, Farida 2008. Pengajaran Membaca di Sekolah Dasar. Jakarta: Bumi Aksara.

Ratnasari, Yunita. 2011. Pengaruh Pergaulan Teman Sebaya Terhadap Minat BacaSiswa Kelas $V$ SD Negeri Bojongsari 1 Kabupaten Purbalingga. Skripsi Sarjana pada FIP UNY Yogyakarta.

Sadirman. 2010. Interaksi dan Motivasi Belajar Mengajar. Jakarta: PT Raja Grafindo Persada

Siang, J. J. 2009. Jaringan Syaraf Tiruan dan

Pemrogramannya

Menggunakan MATLAB. Yogyakarta: Andi.

Sugiyono. 2014. Metode Penelitian Pendidikan Kuantitatif, Kualitatif dan $R \& D$. Bandung: Alfabeta

Sugiyono. 2016. Metode Penelitian Pendidikan Kuantitatif, Kualitatif dan $R \& D$. Bandung: Alfabeta

Susanto, Ahmad. 2013. Teori Belajar dan Pembelajaran di Sekolah Dasar. Jakarta: Kencana Prenadamedia Group. 